\title{
RESPONSES TO STRUCTURAL VIOLENCE: THE EVERYDAY WAYS IN WHICH QUEER AND TRANS MIGRANTS WITH PRECARIOUS STATUS RESPOND TO AND RESIST THE CANADIAN IMMIGRATION REGIME
}

\section{Edward Ou Jin Lee}

\begin{abstract}
This article examines how the Canadian immigration regime socially organizes the everyday lives of queer and trans migrants with precarious status. Drawing from key findings from an institutional ethnographic study, this article maps out the disjuncture between the actual experiences of queer and trans migrants with precarious status and the ideological and textual production of precarious status by the Canadian state. Making explicit this disjuncture reveals how the Canadian immigration regime enacts structural violence upon queer and trans migrants. This article also engages with the response-based approach to violence in order to understand how queer and trans migrants actively respond to this violence. In doing so, this article highlights the ways in which queer and trans migrants respond and resist the structural violence integral to the Canadian state's production of precarious status.
\end{abstract}

Keywords: LGBTQI, immigration, queer and trans migrants, structural violence

Edward Ou Jin Lee $\mathrm{PhD}$ is an assistant professor in the School of Social Work at the University of Montreal, 3150 Jean-Brillant Avenue, Montreal QC, H3T 1N8. Email: wje.lee@umontreal.ca 
In the contemporary global arena, lesbian, gay, bisexual, trans, queer, and intersex (LGBTQI) human rights continue to be debated and contested (Lee, Hafford-Letchfield, PullenSansfaçon, Kamgain, \& Gleeson, 2017). There remain uneven levels of legal and social acceptance of diverse sexual and gender expressions and identities within and across communities, regions, and states (Carroll \& Ramón Mendes, 2017; Lee et al., 2017). Yet, there is a persistent dominant media representation that frames countries of the Global North as LGBTQI human rights leaders, compared to those of an often rigidly homophobic and transphobic Global South ${ }^{1}$ (Cantu, 2009; Jenicek, Lee, \& Wong, 2009; Luibhéid, 2008a; Murray, 2016).

A closer examination of the lives of LGBTQI people in the Global South suggests more complicated realities (Awondo, Geschiere, \& Reid, 2012; Dutta \& Roy, 2012; Ekine, 2013; Lee et al., 2017). Over the past decade, Canada has asserted itself as a global leader in LGBTQI human rights, as well as a "safe haven" for LGBTQI people who are fleeing homophobia or transphobia (Jenicek et al., 2009; Nicol, Gasse-Gates, \& Mulé, 2014). However, this simplistic framing obscures how the movement of LGBTQI people from the Global South to Canada is shaped by the complexities of global capitalism, post-colonial nationalism, and national migration laws (El-Hage \& Lee, 2016).

The international and forced migration of LGBTQI people from the Global South to Canada is thus shaped by a complex set of historical, material, and transnational conditions. Forced migration is often defined as the coerced movement of people due to the interrelated factors of conflict (war, persecution), development projects, international trade agreements, worker mobility regulations, environment (e.g., climate change and natural disasters), and human trafficking (Castles, De Haas, \& Miller, 2014). Shaped by processes from both areas of origin and areas of destination, forced migrations are influenced by a multitude of factors and motivations that obscure the line between "forced" and "voluntary" (Castles et al., 2014). People who are compelled into a migratory process to Canada are caught within the asylum-migration nexus (Castles \& Van Hear, 2005), which is shaped by a confluence of factors (conflict, development, etc.). This nexus suggests that for many people compelled into a migratory process to Canada, forced and economic migrations are intertwined, and may or may not align with factors required to ensure a successful refugee claim. This complex understanding of forced migrations reveals the limits of the legal definition of the "refugee" in fully capturing the set of factors that result in coerced movements (Crépeau et al., 2006).

\footnotetext{
${ }^{1}$ Although the terms "Global South" and "Global North" refer to geographic locations, they also signify a global order shaped by active social processes that organize social, political, and economic inequalities between regions (Castles, De Haas \& Miller, 2014). Informed by colonial and imperial histories, this uneven and unequal international economic and political order suggests that nation-states from the Global North actually do more to cause forced migration than to stop it (Castles, 2003, p. 18).
} 
International Journal of Child, Youth and Family Studies (2019) 10(1): 70-94

Although the terms "migrant" and "refugee" are often used to differentiate between different types of migration, the production of a migrant/refugee binary obscures the complexities of forced migration processes (Macklin, 2005). For example, migrants who are shaped by the asylum-migration nexus often arrive with temporary migrant status, as established by the receiving nation-state (Castles et al., 2014). This production of temporary migrant status, often described as "precarious" status, is conditional, with limited access to citizenship, and results in differential access to social and legal rights (Goldring \& Landolt, 2013). Those with precarious status include visitors, international students, temporary workers, sponsored family members, refugee claimants, and protected persons, along with those detained and undocumented (Goldring, Berinstein, \& Bernhard, 2009).

This article examines how the Canadian immigration regime socially organizes the everyday lives of LGBTQI migrants with precarious status. I draw from my recently completed study (Lee, 2015) to map out the disjuncture between the actual experiences of queer and trans migrants with precarious status and the ideological and textual production of precarious status by the Canadian state. Making explicit this disjuncture reveals how the Canadian immigration regime enacts structural violence upon queer and trans migrants (Lee, 2015). Structural violence is a set of complex and often hidden social processes and practices embedded within policies, institutions, and laws that favour some groups within society over others, resulting in an unequal distribution of life chances and intergenerational social inequities (Mullaly, 2010). I also critically engage with the response-based approach to violence (Kinewesquao \& Wade, 2009; Wade, 1997) in order to understand how queer and trans migrants actively respond to this structural violence.

The response-based approach to violence suggests that victims of violence "invariably resist violence and other forms of oppression, overtly or covertly, depending on the circumstances" (Kinewesquao \& Wade, 2009, p. 205, citing Coates, Todd, \& Wade, 2003). A response to violence is understood as acts of resistance, instead of as simply an effect or impact of violence (Kinewesquao \& Wade, 2009). Although this approach was initially developed within the frame of interpersonal violence (i.e., intimate partner violence and family violence), it has since been used to situate Indigenous peoples' responses to interweaving structural and interpersonal violence shaped by ongoing colonial discourses and practices (Kinewesquao \& Wade, 2009; Todd \& Wade, 1994). In a similar manner, this article aims to highlight the ways in which queer and trans migrants respond to and resist the structural violence integral to the Canadian state's production of precarious status.

\section{The Emergence of Queer and Trans Migration Studies}

Before turning to the literature review, it is important to note that although I engage with sexual and gender identity categories (i.e., lesbian, queer, and trans) ${ }^{2}$, I also recognize these terms'

\footnotetext{
2 The terms lesbian, gay, and bisexual are described as sexual orientations or identities, while trans (transgender or transsexual) or cis (cisgender or cissexual) are described as gender identities (Lee \& Brotman, 2015). A variety of umbrella terms also exist, such as LGBTQI, queer, trans, and so on. These terms emerged from particular historical
} 
historical formation from "specific epistemologies and social relationships that upheld colonialist, xenophobic, racist, and sexist regimes" (Luibhéid, 2005, p. xi). The emergence of various terms (e.g., "gay" and "lesbian", and even "sexuality") as categories of meaning can be traced back to colonial modes of knowledge production that reconfigured Indigenous ways of knowing (Driskill, Finley, Gilley, \& Morgensen, 2011; Haritaworn, 2012; Manalansan, 2003; Massad, 2007). These terms are taken up not only to denote identity, but also to engage with queer and trans theories and politics (see Bastien-Charlebois, 2011; Cohen, 1997; Stryker, 2008). Critical queer and trans theories unpack how social institutions, processes, and practices reproduce heterosexuality (heteronormativity) and the gender binary and the erasure of trans people (cisnormativity), thus operating to reinforce dominant social norms (Cohen, 1997; Stryker, 2008) ${ }^{3}$.

Queer and trans migration studies highlight the relationship between sexuality, gender, and migration in order to disrupt the assumption of the heterosexual and cissexual migrant (Cotton, 2012; Luibhéid, 2008a; Manalansan, 2006; Sears, 2008). Queer and trans migration studies is a multidisciplinary field, drawing from sexuality, international and forced migration, refugee, diaspora, and transnational studies. Knowledge about queer and trans migrants has been produced from researchers across the spectrum of the social sciences and humanities. Some of these scholars draw from queer/trans diasporic critique to examine how sexuality and gender are imbricated into global capitalism and ongoing colonial legacies (Bhanji, 2012; Eng, 1997; Gopinath, 1998; Haritaworn, 2012; Manalansan, 2003; Puar, 1996).

Most of the Canadian and U.S. empirical literature about queer and trans migrants with precarious status focuses on LGBTQI refugees (LaViolette, 2007, 2009; Lee et al., 2017; Murray, 2016; Nicol et al., 2014; Rehaag, 2008, 2009; Ricard, 2011, 2014). There is also scholarship that focuses on same-gender spousal sponsorship (Farber, 2010; LaViolette, 2004; Miluso, 2004; Zaske, 2006), international students (Kato, 1998; Oba \& Pope, 2013), undocumented status (Cruz, 2008; Manalansan, 2014), and detention (Solomon, 2005). Three key themes emerge from this literature: legal implications; multiple identity formation; and broader historical, political, and social dimensions. Although still focused on the refugee process, a growing body of literature examines the broader historical, political, and social dimensions of queer and trans migrant realities (Fobear, 2013; Lee \& Brotman, 2011; Murray, 2016; White, 2013).

A central critique includes interrogating the liberationist narrative in which queer migrations are framed as a simplistic "movement from repression to freedom, or a heroic journey undertaken in search of liberation" (Cantu, 2009, p. xxv). This framing obscures the global and

and geographic contexts and have shifted and changed over time. The term cis is used for people who are not trans and whose gender identity has always aligned with the gender assigned to them at birth (Serano, 2007).

${ }^{3}$ Engaging in queer or trans politics extends these theories into political action that challenges not only normative sexual practices, but any type of dominant social norm, such as immigration reform (De Genova, 2010). However, queer and trans theories and politics have been critiqued for reproducing a white cis gay male subjectivity, and failing to address how sexuality and gender have been historically constructed differently for queer and trans people of colour (Bhanji, 2012; Haritaworn, 2012; Perez, 2005). 
International Journal of Child, Youth and Family Studies (2019) 10(1): 70-94

colonial character of homophobia and transphobia as well as the daily forms of homophobic and transphobic violence that continue to exist in Canada and the United States. The liberationist narrative is reproduced in the media (Jenicek et al., 2009; Roy, 2012) and by LGBTQI refugee claimants in order to successfully navigate the refugee process (Murray, 2016). Scholars also examine how the figure of the LGBTQI refugee in Canada navigates homonational discourses (Murray, 2016; White, 2013) and contributes to the ongoing settler colonial project (Fobear, 2013).

There is also scholarship that focus on how queer and trans migrants navigate undocumented status and detention, especially in the United States (Cruz, 2008; Manalansan, 2014; Rivera-Silber, 2013; Terriquez, 2015). These studies suggest that queer and trans undocumented people experience employment and housing barriers and are often denied access to health and social services. Some studies suggest that queer and trans undocumented people resist through living their everyday lives (Manalansan, 2014) or actively participating in migrant justice organizing, such as by the creation of the "undocuqueer" slogan (Rivera-Silber, 2013; Terriquez, 2015). The few studies that have examined detention suggest that queer and trans migrants who are detained encounter heterocisnormative practices such as not recognizing same-gender couples as families (Lee \& Brotman, 2011), the separation of migrants based on a gender binary with the presumption that everyone is cis (Spade, 2011), and sexual assault of trans women by detention security guards (Solomon, 2005). This type of structural violence is a result of policies and practices which create systemic vulnerability and unevenly distribute life chances for queer and trans migrants (Lee \& Brotman, 2011; Spade, 2011).

Some of this scholarship also explore the links between refugee status and other forms of temporary migrant status (Kato, 1998; Lee \& Brotman, 2011; Murray, 2016). However, there remains an absence of published research that engages in a sustained and in-depth analysis of the links between multiple temporary statuses and how precarious status impacts queer and trans migrants in particular. This article thus aims to address this major gap within the empirical literature, by focusing on the Canadian state's production of precarious status and how this shapes the everyday experiences of queer and trans migrants with precarious status.

\section{Mapping Out the Canadian Immigration Regime}

The findings in this article are from my doctoral study (Lee, 2015), which applied an institutional ethnography methodology. The purpose of the study was to map out the Canadian immigration regime as a ruling regime (G.W. Smith, 1990) that socially organizes the everyday lives of queer and trans migrants with precarious status. Ruling regimes can be described as a complex set of text-mediated processes and practices which flow through multiple sites of power, including political and bureaucratic apparatuses, social institutions, and media (Ng, 2006; G.W. Smith, 1990, 2006).

Institutional ethnography aims "to link local experiences to broader social and global processes, which are not always immediately apparent at the local level” (Ng, 2006, p. 186). Ruling regimes are not fixed entities but instead are a set of social relations driven by individual people, 
International Journal of Child, Youth and Family Studies (2019) 10(1): 70-94

and a series of text-mediated coordinated activities at political and administrative levels ( $\mathrm{Ng}, 2006$; G. W. Smith, 2006). A politico-administrative regime is defined as "institutional sites of regulation and control (that) are merged together ... these kinds of regimes usually have two interrelated pieces of organization: a political apparatus and a bureaucracy" (G. Smith, 1990, p. 25). As a ruling regime, the Canadian immigration regime is organized by state governance, laws and policies, and administrative systems (i.e., institutional bodies such as police, immigration, and detention).

Another key feature of any ruling regime is the ways in which ideological practices present a series of "facts" about that regime that serve to displace and conceal people's actual experiences (G.W. Smith, 1990). Within ruling regimes, ideological regulatory frames are created by individuals in positions of power to produce a set of "facts" about that regime (D. E. Smith, 2005). This series of "facts" in turn obscures how people actually experience a ruling regime. Instead of describing what is actually occurring, these "facts" that are reproduced within text-based discourses become ideologically based "codes" that reproduce particular modes of social representation. These "codes" are thus mediated by texts located either within (i.e., Immigration and Refugee Board [IRB] policies) or adjacent to (i.e., articles in the media) the Canadian immigration regime. The institutional ethnography methodology thus investigates the disjuncture between ideological accounts and people's actual experiences (Kinsman \& Gentile, 2010). In this article, I map out the textually mediated processes that socially organize the migration paths of queer and trans migrants from the Global South. I investigate how the Canadian immigration regime produces ideologically based "facts" about precarious status that conceal how queer and trans migrants actually experience precariousness.

\section{Research Design}

My doctoral study was conducted in four parallel phases, drawing from four different but interconnected data sets: (a) written notes about personal experiences, (b) secondary data from eight interview transcripts from a previously completed research project, (c) primary data from five interviews conducted for the present study, and (d) 49 policy and media texts dating from 2006 to 2014 (Lee, 2015). Although I list these data sets linearly, the research process was iterative as I moved back and forth between data collection and analysis. This cyclical process affirms that no institutional ethnographic study is put together in the same manner (D. E. Smith, 2006).

For phase 1, I drew from my social location and own experiences as a scholar-activist in order to present the research problem my study addressed - the disjuncture between an ideological account of queer and trans migration and actual queer and trans migrant experiences. During phase 2, I analyzed eight interviews that I had previously conducted as research coordinator for the Speak Out! LGBTQ refugee research project, a community-based project that explored the experiences of LGBTQ refugees in Canada (Lee \& Brotman, 2011). For phase 3, I mapped out the text-mediated processes that were emerging from my data analysis. I developed a practice of listening for and asking about texts (DeVault \& McCoy, 2006). For phase 4, I collected and analyzed policy and media texts in conjunction with my data analysis of the interviews. These 
International Journal of Child, Youth and Family Studies (2019) 10(1): 70-94

texts included websites, press releases, and published PDF files, along with media articles and research publications.

In order to ensure a rigorous practice of critical inquiry, I developed a set of principles and procedures, adapted from other scholars (DeVault \& McCoy, 2006; Campbell \& Manicom, 1995; D. E. Smith, 2006). I also asked myself a series of reflexive questions throughout the research process, including: What are the everyday experiences and daily activities of queer and trans migrants? Is any coordination of activities happening here? What are the possible texts that may be linked to a particular set of activities? How might this coordination of activities be linked to a variety of social institutions or the Canadian immigration regime?

\section{Evaluation of Findings}

In contrast to most forms of qualitative research, an institutional ethnography does not use measures of trustworthiness or validity. Instead, the strength of the linkages among actual experiences, texts, and the coordination of activities are what is evaluated. I thus evaluated the degree to which ideological practices related to precarious status are reproduced across texts, along with the breadth and depth of the text-based processes that socially organize the realities of queer and trans migrants with precarious status. This type of evaluation requires a "faithfulness to the actual work processes that connect individuals and activities in the various parts of an institutional complex (ruling regime). Rigor comes not from technique — such as sampling or thematic analysis - but from the corrigibility of the developing map of social relations" (DeVault \& McCoy, 2006, p. 33). I also evaluated the degree of recursivity within the findings in order to map out "how things happen here in the same way they happen over there ... recurring events or recurring use of words ... show(ing) a pattern in the world - something is organized to recur" (Campbell \& Gregor, 2008, p. 69). Recursivity is demonstrated by the strength of text-based patterns and their degree of recurrence within everyday life.

\section{Findings and Analysis}

In this section, I map out how the Canadian immigration regime - state governance, laws and policies, and administrative systems (i.e., institutional bodies such as police, immigration, and detention) - shapes the everyday experiences of queer and trans migrants with precarious status. More specifically, I examine the disjuncture between the ideological production of precarious status and the actual queer and trans migrant experience of precarity. These findings examine how each participant navigated visa/permit eligibility criteria, crossed borders to enter Canada with precarious status, and shifted between precarious statuses. I also consider the ways in which heterocisnormative processes inform the Canadian immigration regime's production of precarity, resulting in particular forms of structural violence towards queer and trans migrants.

This ideological account and erasure of structural violence shapes contextualized negative social responses towards queer and trans migrants. Social responses refer to the systematic manner in which victims of oppression are blamed as individually responsible for the various forms of 
International Journal of Child, Youth and Family Studies (2019) 10(1): 70-94

interpersonal and structural violence (Kinewesquao \& Wade, 2009). In this case, I consider the ways in which state and non-state actors perpetuate contextualized negative social responses towards migrants generally and towards queer and trans migrants specifically. Finally, I consider how strategies used by queer and trans migrants to navigate their precarity can be understood as a response to structural violence and resulting contextual negative social responses.

\section{The Ideological Account of Precarious Status versus Actual Experiences}

The Immigration and Refugee Protection Act (IRPA; 2001) outlines five categories of people who reside in Canada: citizen, permanent resident, Indian, refugee, and temporary resident. The "immigration objectives" presented for the temporary resident category include "trade, commerce, tourism, international understanding and cultural, educational and scientific activities" (IRPA, 2001, s. 3[1]). This category is separated into three classes: visitors, students, and workers. These classes within the temporary resident category are grouped together on the Department of Citizenship and Immigration Canada's (CIC; 2014b) webpage explaining how to apply for a visitor visa.

In contrast, refugee protection is in a separate section in the IRPA (2001, Part 2), as its main objectives are textually described as distinct from the temporary resident categories. The refugee objectives are linked to "Canada's international legal obligations" and described as an "expression of Canada's humanitarian ideal", meant to provide a "safe haven" for those facing persecution, torture, or cruel and unusual treatment (IRPA, 2001, s. 3[2]). Temporary resident and refugee categories are textually separated throughout the IRPA, its regulations, and the CIC website, implying that the migration flows of these categories are distinct.

However, a participant's decision to apply for visitor, student, or worker status was shaped by having lived either in the United States with precarious status or in a context of overlapping generalized, political, and heterocisnormative violence in the country of origin. Eleven out of the 13 participants from my doctoral study entered Canada (mostly between 2006 and 2011) as temporary residents; two filed refugee claims at the Canada-U.S. land border. Four entered as visitors, six entered as international students, and one entered as a temporary foreign worker. Their entry as temporary residents and, for some, their subsequent refugee claims, were inextricably tied to their forced-migration context. The textual separation of temporary resident and refugee categories reproduces an ideological regulatory frame of precarious status that obscures the everyday realities of queer and trans people from the Global South who have been compelled to leave their countries by taking on any precarious status available to them.

At the same time, migrants with precarious status are textually linked together through the term "foreign national". The IRPA (2001) describes a "foreign national" as "a person who is not a Canadian citizen or permanent resident, and includes a stateless person" (s. 2[1]). The "foreign national" label applies not only to people seeking entry but to all migrants with precarious status living in Canada. Although temporary residents and refugees are textually separated, the foreign national is textually imbricated into policies specific to migrant exclusion, surveillance, and 
International Journal of Child, Youth and Family Studies (2019) 10(1): 70-94

removal. The foreign national thus serves as the ideological tool through which temporary resident and refugee categories can remain textually divided, while policies related to migrant exclusion can be operationalized on all migrants with precarious status.

\section{The Temporary Resident Visa (TRV) as Barrier to Migration and Site of Structural Violence}

In this section, I explore how participants Anthony, Sarah, and Lana ${ }^{4}$ struggled with barriers to obtaining a temporary resident visa (TRV), which would allow them to enter Canada with precarious status. The TRV application, imposed on 147 nation-states mostly from the Global South (CIC, 2014b), operates as a central organizing tool to determine who will be accepted or refused entry. A TRV is issued to a foreign national who applies for a visitor visa or study/work permit, meets the requirements related to the temporary resident class, is "not inadmissible", and will leave Canada at the end of an authorized time period (Immigration and Refugee Protection Regulations [IRPR], 2014, s. 9). In order to be eligible for a TRV, applicants must undertake to leave Canada at the end of their stay, have enough money to maintain themselves and return home, not intend to work or study unless authorized, have no criminal record, be law abiding, not be a security risk, be willing to provide documents upon request, and be in good health (CIC, 2014a). The TRV application form also reproduces the gender binary through its use of male and female categories.

The participants encountered obstacles to fulfilling the TRV eligibility requirements. One of the main challenges was meeting the requirement to obtain the "approval" of a non-state Canadian actor via an acceptance letter from a post-secondary institution (student), invitation letter (visitor), or signed job offer/employment contract (worker). As a Muslim gay man from Southeast Asia, Anthony spent many years working in the United States. After a friendly encounter with a Canadian couple, they offered him the possibility of attending a language centre that they operated while working for them at the same time. Anthony's study permit application process was subverted by the couple to include a work requirement, which is not legally allowed on a study permit.

In contrast, as a working-class gay and gender nonconforming person living in the Caribbean, Lana's everyday life was marked by homophobic and transphobic violence, which included verbal harassment and physical assault. While Lana was evading this violence by staying at a friend's home, her friend informed her of a recruitment agency that was hiring temporary foreign workers to work at a Canadian hotel:

My friend, she told me about this work program that was coming to Canada and I said I would give it a try.... I was very suicidal ... because it's like, before I die from someone who is homophobic, I'm ready to do it myself. That was always my theme, right? ... And then there comes this light in the tunnel. (Lana)

\footnotetext{
${ }^{4}$ All participant names included in this article are pseudonyms.
} 
International Journal of Child, Youth and Family Studies (2019) 10(1): 70-94

Lana was not certain that she would be able to emigrate because the recruitment agency that hired her had confiscated her passport; however, it was returned to her on the day of her departure. It was also worrying for Lana that she did not receive the signed job offer (employment contract) or her approved work permit until after she arrived in Canada.

Income-related criteria can also be a barrier. As a transwoman from Northern Africa, Sarah was working as a café manager and experiencing everyday harassment and threats to her life due to her trans identity. Sarah reached out to numerous LGBTQI human rights organizations in order to make plans to leave. After unsuccessful attempts at obtaining a visa elsewhere, Sarah connected with people from Canada who provided her with an invitation letter and financial support. Upon submitting her visitor visa application, Sarah had to navigate a phone call from the Canadian embassy that was part of the verification process:

The visa delivery doesn't happen in Algeria, it happens in Paris.... They called me. I was working, my mother, she said to me, "You received a call from the embassy. They asked how much you earned and all." Me, I falsified everything because I don't make a lot (of money). I said, "I earn (enough). I am OK. I earn. I can cover my needs here in Canada and everything." (Sarah, translated from French)

Sarah's decision to falsify her income in order to obtain a visitor visa to Canada was intimately tied to her economic status, the transphobic violence she was experiencing on a daily basis, and her country's political context. The TRV processing procedures also reveal how the application process to Canada is shaped by contemporary international relations, situated within a FrenchNorthern African historical colonial context.

These examples highlight the disjuncture between these participants' actual experiences of the TRV application process and how the Canadian immigration regime ideologically frames temporary resident categories. These participants' migration trajectories are clearly situated within the migration-asylum nexus, as their motivations to migrate did not fit the narrow parameters within the temporary resident categories through which they arrived. And yet, this forced migration context had no bearing on their gaining TRV approval, even though they all eventually filed refugee claims. The Canadian immigration regime thus places temporary resident migrants in discrete categories of visitor, student, worker, or refugee claimant. The operationalization of these categories, notably through the TRV application form, imposes barriers for queer and trans migrants, and indeed all migrants, to obtaining visas to enter Canada. Before and after obtaining their TRV, Anthony, Sarah, and Lana faced various forms of structural violence, such as being compelled to agree to work under a student visa, being forced to obtain a visa from France, or having to hand over a passport to a recruitment agency.

\section{Border Crossings as Sites of Structural Violence and Contextualized Negative Social Responses}

In the following section, I explore the ways in which the ideological account of precarious status established by the Canadian immigration regime embolden state actors to apply 
contextualized negative social responses to migrants. Ligeia and Sayad's migration paths illustrate how border crossings operate as a site of structural violence for queer and trans migrants. Ligeia was born in North Africa within a Muslim family and eventually entered Canada with a study permit. Ligeia arrived at the Canadian airport and was questioned at an immigration office:

He asked me ... "Are you going to a specific place?... What is the place?... Who are the people that you're going to be living with?" and all these crazy questions.... He gave me the study permit and this is real, it will always stay in my mind. His features got a bit severe, strict and he was like, "See that date there, you're not allowed to stay in Canada for that date" and he didn't tell me that you can renew. He was like ... "If you stay after that date, then we'll have problems" and the look, the tone, everything, oh my god ... you start to feel as a stranger. (Ligeia)

In contrast, the immigration officers responded differently when Sayad and his partner crossed the border. Sayad is a university-educated gay man who fled Azerbaijan with his partner after their families discovered their relationship and threatened their lives. Upon arriving at a Canadian airport with a visitor visa, Sayad and his partner immediately filed a refugee claim. They were subsequently held at the airport for two days of interrogations and placed in detention:

The first interrogation was basically just, based on ... questions related to our documents and passport. They took all our fingerprints.... They basically asked... "How did you come to Canada? What was the route? What kind of visa? How did you come? Why do you declare refugee status?" And the next day, they had the actual interview, which basically determined the eligibility to claim refugee status... My interview went very smooth. However, my partner's wasn't that good because his English at that time wasn't very well, so they had an interpreter ... and there were some misinterpretations and so the officer who was interviewing, she had some concerns. She didn't believe what my partner said. Even though what he said was what I said during separate interviews ... that same officer, she made a decision to detain us until the next hearing. (Sayad)

Although the initial concerns by an immigration officer were related to translation problems by an interpreter for Sayad's partner, they were both detained because Sayad was deemed a "flight risk" based on his connections with people in the United States. Classification of a migrant as a flight risk is one of four reasons that an immigration officer can use to justify the detention of a migrant with precarious status (IRPA, 2001). Although Sayad and his partner were legally identified as refugee claimants, the moment Sayad was named a flight risk they were also identified as foreign nationals who were potential threats to the security of Canadian citizens, which provided justification for their detention.

Ultimately, Sayad and Ligeia's pre-migration experiences of violence were irrelevant to the border agents. The ideological account of precarious status emboldened the border agents to 
International Journal of Child, Youth and Family Studies (2019) 10(1): 70-94

threaten Ligeia and disbelieve Sayad's partner. These text-mediated processes related to precarious status give border agents the power to apply immigration entry procedures in ways that reinforce state power and justify structural violence. It was not only what was said and decided, but also the manner in which it was spoken that reveals how power operated. In both cases, the border agents reproduced contextualized negative social responses towards migrants with precarious status, which suggests that migrants are possible liars or security threats.

\section{Responses to Violence: Mobilizing Informal Support Networks and Becoming a Refugee Claimant}

In this section, I highlight the ways in which Lana, Sarah, and Anthony responded to the structural violence attached to their precarious status by mobilizing an informal support network and filing a refugee claim from within Canada. Before turning to how these participants mobilized support, I describe the structural barriers imposed by the Canadian immigration regime for migrants to access the inland refugee claim process. As I described previously, the ideological regulatory frame of precarious status produces a textual separation between the temporary resident and refugee categories. The IRPA regulations define a "refugee claimant" as "a person who has made a claim for refugee protection in Canada or at a port of entry" (IRPR, 2014, p. 296). The IRPA (2001) does not explicitly state that individuals who enter Canada as temporary residents have the right to file a refugee claim. Indeed, the only way that migrants can file refugee claims, and thus become refugee claimants in Canada, is at a port of entry (i.e., border crossing, seaport, airport). This omission within the IRPA is significant because entering as a temporary resident is one of the only pathways to access the inland refugee claim process. This omission is also reflected in the absence of policies and programs within educational institutions and worksites that employ temporary workers regarding the possibility of filing inland refugee claims.

Lana, Sarah, and Anthony each had a unique set of circumstances that led them to file a refugee claim. Each of them connected with individuals who helped them in their process. They reached out to family members, friends, and, sometimes, random strangers who helped them to navigate their TRV application process and their transition from temporary resident to refugee claimant. In some cases, they received support on a transnational scale, either from people living in Canada prior to their arrival or from people living in their country of origin post-migration.

Sarah, for example, knew very quickly that she would file a refugee claim and did so with the assistance of her informal support network - the same individuals who had helped her to migrate to Canada by providing an approval letter and financial support. Sarah attributed the ease with which she navigated the refugee process to the economic, social, and information-related resources and support she received. However, it was Sarah who initiated contact with these key individuals and convinced them to provide letters, financial support, and other help.

In contrast, Lana and Anthony did not make the decision to file a refugee claim until after they arrived in Canada. After a search of multiple websites, Anthony learned that he could apply for refugee status due to his fear of persecution as a gay man. He found this information after living 
International Journal of Child, Youth and Family Studies (2019) 10(1): 70-94

in Canada for over a year with a study permit but under a work contract (enforced by the Canadian couple who provided his study permit). During this time, Anthony was isolated and did not initially have access to support. It was only after Anthony refused to continue working for the Canadian couple and transitioned from a student to a visitor visa that he had the time to reach out to individuals for support. Anthony eventually contacted a refugee lawyer and other individuals who would support him in this refugee process. Lana's decision to apply for refugee status was informed by a chance encounter with someone in an online gay chatroom:

So I went on [gay website], and I met this guy. His name was [Gary]... I don't even know this guy and he just come up online and he just start talking to me. Anyways, I just start talking... He called me, and then he said to me, "Why are you so nice?", he said, "You sound like somebody who was crying."... I just burst into tears... I tell him my situation. He's like, "Oh my god, you know, you don't have to live like that. There's a way that you can claim refugee status." (Lana)

Through phone conversations with this person, Lana was referred to a refugee lawyer. Although Lana was very grateful for the support provided by this stranger, it is important to note that Lana would not have received this support unless she took the risk to disclose her situation.

\section{Discussion and Conclusion}

In this section, I summarize this study's key findings and analysis as well as discuss their relevance to existing scholarship. I also explore implications for developing a response-based approach for practice with queer and trans migrants and consider the possibilities of engaging in reflexive ways of knowing. In my findings, I mapped out the ways in which the Canadian immigration regime produced the ideological regulatory frame of precarious status and socially organized the lives of queer and trans migrants from the initial visa or permit application to postarrival experiences.

My findings illustrate how the TRV requirements result in a nationality-based differential eligibility threshold for entry into Canada (targeting the Global South), revealing a racialized and neoliberal geopolitical division of precarious status. These eligibility criteria, as part of the TRV application process, enact structural violence, resulting in an uneven distribution of life chances. The use of male and female categories in the TRV application form reproduces a gender binary that makes trans and gender-nonconforming migrants systematically more vulnerable to a cisnormative immigration regime. Moreover, the consequences of "telling the truth" in the TRV application process for most participants would have been ineligibility to enter Canada and further exposure to heterocisnormative, generalized, and political violence. In some cases, the choice of whether to lie or tell the truth was the choice of whether to live or die.

In addition, the textual separation of temporary resident and refugee claimant status produces the ideological "fact" that migrants naturally flow into distinct migrant categories. This 
ideological framing lays fertile ground for the immigration regime to become a site of structural violence by reproducing the refugee-migrant binary (Macklin, 2005) through the use of migrant classification schemes that do not correspond with the everyday realities of queer and trans migrants with precarious status. The actual experiences of Sarah, Anthony, and Lana illustrate that temporary resident status is a major pathway for queer and trans migrants to access Canada's inland refugee claim process. Indeed, if they had not been eligible for TRVs, they would never have been able to file refugee claims. The textual erasure of the TRV as a key pathway to becoming a refugee reveals the degree to which the Canadian immigration regime ignores the forced migration context of queer and trans people from the Global South.

Prior to the start of WorldPride 2014 (an international LGBTQI human rights festival) in Toronto, 10 Ugandan "gay rights advocates" were refused entry into Canada due to lack of travel history, no family ties in Uganda, and insufficient funds (Keung, 2014). More recently, some LGBTQ Tunisian activists were denied visas to enter Canada (Larivée-Tourangeau, 2017). In both cases, one reason for the refusal was the fear that these activists would seek refugee status upon arrival, as did one LGBTQ Tunisian activist whose initial visa application to attend a human rights conference in Montreal was refused (Larivée-Tourangeau, 2017). These experiences reveal how the TRV process is used as a racialized, gendered, and sexualized tool to exclude queer and trans people from the Global South, in ways that prioritize economic concerns over humanitarian ones.

Recently, the IRB implemented guidelines for refugee claims based on sexual orientation and gender identity and expression (SOGIE; IRB, 2017). These guidelines have been hailed by policymakers and advocates as an important step forward in protecting the rights of LGBTQI refugees (Lee et al., 2017). Although there is certainly merit to these claims, focusing only on improvements to the refugee determination system obscures the fact that the Canadian immigration regime remains designed to block the migration of the vast majority of queer and trans people from the Global South who are compelled to flee their countries. This narrow focus on improvements also fortifies the liberationist narrative (Cantu, 2009; Murray, 2016) in which Canada is the site of freedom and a safe haven for LGBTQI refugees in contrast to "backwards" homophobic and transphobic countries. This ideological framing of precarious status (i.e., the separation of temporary resident and refugee categories) feeds into the liberationist narrative by making invisible the various policies and practices (e.g., the TRV) that embolden state actors (e.g., immigration agents) and non-state actors (e.g., community workers) to surveil and interrogate queer and trans migrants with precarious status as foreign nationals who are possible security threats.

\section{Developing a Response-Based Approach to Practice with Queer and Trans Migrants}

In order to develop a response-based approach (Kinewesquao \& Wade, 2009) to practice with queer and trans migrants with precarious status, practitioners should be keenly aware of how the Canadian immigration regime produces an ideological account of precarious status and promotes the liberationist narrative. This framing and narrative obscure queer and trans migrant 
realities and their actual experiences of structural violence enacted by the Canadian immigration regime. Developing this analysis will assist practitioners to be mindful of how these social processes shape the contextualized negative social responses (Kinewesquao \& Wade, 2009) imposed on migrants generally and queer and trans migrants specifically, including the blaming of migrants either as non-genuine or as security threats (i.e., terrorists).

The IRB's SOGIE-based guidelines will improve the refugee process and some positive decisions are certainly given for LGBTQI refugee claims. However, the overemphasis on Canada as a safe haven for LGBTQI refugees makes it very difficult to point out the heterocisnormative processes and overall structural violence intrinsic to the Canadian immigration regime. Service providers should develop strategies to co-construct analysis with queer and trans migrants about these social processes and push back against state and non-state actors that reproduce ideologically-based accounts and narratives (i.e., the textual separation of temporary resident and refugee categories within the IRPA, and the justification of the TRV as having been designed to assess entry of temporary residents - not to block entry to possible refugee claimants from the Global South). This may assist queer and trans migrants to not take personal responsibility for structural issues.

Within a direct practice context, it is helpful to explicitly affirm and validate the resourcefulness of queer and trans migrants and their varied responses to structural violence. The participants from my study actively responded to both the TRV eligibility criteria and immigration officers. One resistance strategy used by participants was the engagement of "intentional institutional capture" (Eastwood, 2006), whereby they actively translated their objectives (entry into Canada) into a text-mediated process (e.g., TRV permit approval document or passport) that was recognizable to various state actors (e.g., border agents). These microactions reveal the subtle but powerful ways in which queer and trans migrants navigate, contest, subvert, and resist ideological practices, thus refusing to give in to a regime organized to exclude them.

Another key strategy queer and trans migrants with precarious status use to respond to violence is the mobilization of an informal and transnational support network. Such networks serve as crucial informal pathways for queer and trans migrants to learn more about the specific policies and institutions that regulate their lives in order to develop collective strategies that directly respond to and resist the Canadian immigration regime. At times, informal support was fostered due to queer and trans migrants connecting with a key non-state actor (e.g., a community worker) that put them in contact with other individuals. Informal supports also emerged through virtual and in-person chance encounters. Regardless of how support was mobilized, the mobilization serves as an example of a response to state-based violence initiated by queer and trans migrants themselves. However, queer and trans migrants may not be aware of the extent to which their microactions - deciding to reach out to people, disclosing key information about their situation, and requesting support - are acts of resistance. Indeed, informal support networks become sites of politicization reorienting the mundane to "hint at political potentials, gesture to alternative narratives and enable an openness to multiple futures" (Manalansan, 2014, p.106). 
International Journal of Child, Youth and Family Studies (2019) 10(1): 70-94

For those who work with queer and trans migrants, it is helpful to critically reflect upon how informal support networks may be built in a more organized manner. Such networks can be fostered by integrating their development into community organizing or service provision models. This strategy encourages "learning in social action" (Foley, 1999), which highlights the importance of informal processes in learning to build social movements. As a scholar-activist, I seek to extend the usefulness of my study, and this article, in order to further contribute to queer and trans migrant justice and movement building.

\section{Activist Scholarship and Engaging with Reflexive Ways of Knowing}

To conclude, I critically reflect upon how my findings and analysis from this article (and my doctoral study) are grounded by my posture as a scholar-activist and reflexive ways of knowing. First, my knowledge claims are anchored by my standpoint as a queer and gender nonconforming migrant-turned-citizen and scholar-activist of colour. I draw from my long-term involvement with queer and trans people of colour and in migrant movement-building across academic, community, and activist spaces to unpack "social relations and organization in which our everyday doings participate but which are not fully visible to us” (D. E. Smith, 2005, p. 1).

Through my involvement with individual support work and public anti-deportation campaigns, I have witnessed the impact of structural violence and contextualized negative social responses on the lives of queer and trans migrants fighting for their lives. I have heard story after story of queer and trans migrants who were retraumatized (leading to, e.g., depression, anxiety, suicide) as they navigated the Canadian immigration regime. I have lost track of the number of people who have told me that the immigration and refugee process felt like a prison, or was literally or figuratively killing them. These conversations have led me to question how Canada could be framed as a safe haven for LGBTQI people in the midst of state-sanctioned brutality. Although outside the scope of this article, I note that this experience also led me to resituate and rehistoricize (Kinsman \& Gentile, 2010) my own family's migration path.

My knowledge claims thus question the assumed standard of "objective" knowledge production (Bannerji, 2011; Hill-Collins, 2000; Naples, 1996; D. E. Smith, 1990). The pursuit of objective knowledge implicitly situates the researcher as a universal, yet invisible, subject whose interests and biases are concealed, thus obscuring the relations of power that socially organize what counts as valid knowledge (Naples, 1996; D. E. Smith, 2005). Historical and contemporary modes of knowledge production are imbued with colonial and imperial logics that were developed in the 19th century during an era of colonization, slavery, indentured labour, and empire building (Bannerji, 2011; Lowe, 2006; Simpson, 2014). Lisa Lowe (2006) suggests engaging with the politics of "lacking knowledge" to recover erased global histories of colonial violence.

The recovery of these colonial histories reshapes how contemporary international migrations of queer and trans people are understood (see Alexander 2005; Driskill et al., 2011; Dutta \& Roy, 2014; El-Hage \& Lee, 2016; Luibhéid, 2008a, 2008b; Manalansan, 1997; Walcott, 2006). For example, Canadian immigration policies and practices cannot be untied from the 
colonial logics that inform policies and practices towards Indigenous peoples (Lee, 2015). Indeed, there was a state entity called the "Department of Immigration and Colonization" from 1917 to 1936 (Library and Archives Canada, 2014; Lee, 2015). From 1936 onwards, the term "colonization" was dropped from subsequent departments that focused on immigration, citizenship, and so on. However, immigration and colonialism continue to be intertwined, as one sees when considering how newcomer settlement programs are being implemented on unceded land. How might this shift in analysis reframe our understanding of how queer and trans migrants respond to the Canadian immigration/colonization regime (see Lee, 2018)? What kinds of knowledges and solidarities may by produced in analyzing the colonial histories that differently inform the lives of queer and trans migrants from the Global South and two-spirit ${ }^{5}$ and LGBTQI Indigenous people in Canada?

\footnotetext{
${ }^{5}$ Prior to colonization, LGBTQ and two-spirit people occupied valued social positions within "the shared culture of a Native nation, which through kinship, economics, social life, or religion linked all Native people in relationship" (Morgensen, 2011, p. 135). For more information see Meyer-Cook and Labelle (2004).
} 
International Journal of Child, Youth and Family Studies (2019) 10(1): 70-94

\section{References}

Alexander, M.J. (2005). Pedagogies of crossing: Meditations on feminism, sexual politics, memory, and the sacred. Durham, NC: Duke University Press.

Awondo, P., Geschiere, P., \& Reid, G. (2012). Homophobic Africa? Toward a more nuanced view. African Studies Review, 55(3), 145-168. doi:10.1017/S0002020600007241

Bannerji, H. (2011). Demography and democracy: Essays on nationalism, gender and ideology. Toronto, ON: Canadian Scholars.

Bastien-Charlebois, J. (2011). Pour une sensibilité intersexe. La revue canadienne de service social, 28(1), 157-162.

Bhanji, N. (2012). Trans/scriptions: Homing desires, (trans)sexual citizenship and racialized bodies. In T. T. Cotton (Ed.), Transgender migrations: The bodies, borders, and politics of transition (pp. 157-175). New York, NY: Routledge.

Campbell, M., \& Gregor, F. (2008). Mapping social relations: A primer for doing institutional ethnography. Toronto, ON: University of Toronto Press.

Campbell, M., \& Manicom, A. (1995). Knowledge, experience, and ruling: Studies in the social organization of knowledge. Toronto, ON: University of Toronto Press.

Cantu, L (2009). The sexuality of migration: Border crossings and Mexican immigrant men. New York, NY: New York University Press.

Carroll, A., \& Ramón Mendos, L. (2017). State-sponsored homophobia: A world survey of sexual orientation laws: criminalisation, protection and recognition. Geneva, Switzerland: International Lesbian, Gay, Bisexual, Trans and Intersex Association.

Castles, S., De Haas, H., \& Miller, M. J. (2014). The age of migration: International population movements in the modern world. (5th ed.). New York, NY: Guildford.

Castles, S., \& Van Hear, N. (2005). Developing DFID's policy approach to refugees and internally displaced persons [Report to the Conflict and Humanitarian Affairs Department]. Oxford, UK: Refugee Studies Centre.

Coates, K., Todd, N., \& Wade, A. (2003). Shifting terms: An interactional and discursive view of violence and resistance. Canadian Review of Social Policy, 52, 116-122.

Cohen, C. J. (1997). Punks, bulldaggers, and welfare queens: The radical potential of queer politics? GLQ: A Journal of Lesbian and Gay Studies, 3(4), 437-465.

doi:10.1215/10642684-3-4-437 
International Journal of Child, Youth and Family Studies (2019) 10(1): 70-94

Cotton, T. T. (Ed.). (2012). Transgender migrations: The bodies, borders, and politics of transition. New York, NY: Routledge.

Crépeau, F., Nakache, D., Collyer, M., Goetz, N. H., Hansen, A., Modi, R., ... van Willigen, L. H. M. (2006). Forced migration and global processes: A view from forced migration studies. Lanham, MD: Rowman \& Littlefield.

Cruz, C. (2008). Notes of immigration, youth, and ethnographic silence. Theory into Practice, 47(1), 67-73. doi:10.1080/00405840701764797

De Genova, N. (2010). The queer politics of migration: Reflections on "illegality" and incorrigibility. Studies in Social Justice, 4(2), 101-126. doi:10.26522/ssj.v4i2.997

Department of Citizenship and Immigration Canada. (2014a). Applying for a visitor visa (Temporary Resident Visa - IMM 5256). Retrieved from http://www.cic.gc.ca/english/information/applications/guides/5256ETOC.asp

Department of Citizenship and Immigration Canada. (2014b). Entry requirements by country/territory. Retrieved from http://www.cic.gc.ca/english/visit/visas-all.asp

De Vault, M. L., \& McCoy, L. (2006). Institutional ethnography: Using interviews to investigate ruling relations. In D. E. Smith (Ed.), Institutional ethnography as practice (pp. 15-44). Lanham, MD: Rowman \& Littlefield.

Driskill, Q.-L., Finley, C., Gilley, B. J., \& Morgensen, S. L. (Eds.). (2011). Queer indigenous studies: Critical interventions in theory, politics and literature. Tucson, AZ: The University of Arizona Press.

Dutta, A., \& Roy, R. (2014). Decolonizing transgender in India: Some reflections. TSQ: Transgender Studies Quarterly, 1(3), 320-335. doi:10.1215/23289252-2685615

Eastwood, L. E. (2006). Making the institution ethnographically accessible: UN document production and the transformation of experience. In D. E. Smith (Ed.), Institutional ethnography as practice (pp. 181-198). Lanham, MD: Rowman \& Littlefield.

Ekine, S. (2013). Contesting narratives of queer Africa. In S. Ekine \& H. Abbas (Eds.), Queer African reader (pp. 78-91). Dakar, Senegal: Pambazuka.

El-Hage, H. \& Lee, E. J. (2016). LGBTQ racisés: Frontières identitaires et barrières structurelles [LGBTQ racism: Identity frontiers and structural barriers]. Alterstice: Revue Internationale de la Recherche Interculturelle. 6(2), 13-27. doi:10.7202/1040629ar

Eng, D. L. (1997). Out here and over there: Queerness and diaspora in Asian American studies. Social Text, 52/53, 31-52. doi:10.2307/466733 
International Journal of Child, Youth and Family Studies (2019) 10(1): 70-94

Farber, S. E. (2010). Presidential promises and the Uniting American Families act: Bringing same-sex immigration rights to the United States. Boston College Third World Law Journal, 30, 329-357. Retrieved from http://lawdigitalcommons.bc.edu/twlj/vol30/iss2/4

Fobear, K. (2013). Queer settlers: Questioning settler colonialism in LGBT asylum processes in Canada. Refuge: Canada's Journal on Refugees, 30(1), 47-56. Retrieved from http://pi.library.yorku.ca/ojs/index.php/refuge/article/view/38602

Foley, G. (1999). Learning in social action: A contribution to understanding informal education. New York, NY: Zed Books.

Goldring, L., Berinstein, C., \& Bernhard, J. K. (2009). Institutionalizing precarious migratory status in Canada. Citizenship Studies, 13(3), 239-265. doi:10.1080/13621020902850643

Goldring, L., \& Landolt, P. (2013). The conditionality of legal status and rights: Conceptualizing precarious non-citizenship in Canada. In L. Goldring \& P. Landolt (Eds.), Producing and negotiation non-citizenship: Precarious legal status in Canada (pp. 3-30). Toronto, ON: University of Toronto Press.

Gopinath, G. (1998). Nostalgia, desire, disapora: South Asian sexualities in motion. In R. Leong (Ed.), Asian American sexualities: Dimensions of the gay and lesbian experience (pp. 206216). New York, NY: Routledge.

Haritaworn, J. (2012). Colorful bodies in the multikulti metropolis: Vitality, victimology and transgressive citizenship in Berlin. In T. T. Cotton (Ed.), Transgender migrations: The bodies, borders, and politics of transition (pp. 11-31). New York, NY: Routledge.

Hill-Collins, P. (2000). Black feminist thought: Knowledge, consciousness and the politics of empowerment. New York, NY: Routledge.

Immigration and Refugee Protection Act, SC 2001, c. 27. Retrieved from http://lawslois.justice.gc.ca/eng/acts/I-2.5/

Immigration and Refugee Board (IRB). (2017). Chairperson's guideline 9: Proceedings before the IRB involving sexual orientation and gender identity and expression. Retrieved from https://irb-cisr.gc.ca/en/legal-policy/policies/Pages/GuideDir09.aspx

Immigration and Refugee Protection Regulations (SOR/2002-227). (2014). Retrieved from the Department of Justice Canada website: https://laws-lois.justice.gc.ca/eng/regulations/sor$\underline{2002-227 /}$

Jenicek, A., Lee, E., \& Wong, A. (2009). "Dangerous shortcuts": Media representations of sexual minority refugees in the post-9/11 Canadian press. Canadian Journal of Communications, 34(4), 635-658. Retrieved from http://www.cjconline.ca/index.php/journal/article/view/2119 
International Journal of Child, Youth and Family Studies (2019) 10(1): 70-94

Kato, N. (1998). Working with gay, lesbian and bisexual international students in the United States. International Educator, 8(1). Retrieved from http://www.indiana.edu/ overseas/lesbigay/kato.html

Keung, N. (2014, May 22). Ugandan gay activists denied visas to World Pride conference. thestar.com. Retrieved from http://www.thestar.com/news/gta/2014/05/22/ugandan_gay_activists_denied_visas_to_worl d_pride_conference.html

Kinewesquao, \& Wade, A. (2009). Taking resistance seriously: A response-based approach to social work in cases of violence against Indigenous women. In S. Strega \& S. A. Esquao (Eds.), Walking this path together: Anti-racist and anti-oppressive child welfare (pp. 204220). Winnipeg, MB: Fernwood.

Kinsman, G., \& Gentile, P. (2010). The Canadian war on queers: National security as sexual regulation. Vancouver, BC: UBC Press.

Larivée-Tourangeau, E. (2017, August 4). Ce n'est pas demain que les homosexuels étrangers envahiront le Canada [It's not tomorrow that homosexual foreigners will invade Canada]. Vice. Retrieved from https://www.vice.com/fr_ca/article/3kd3jy/ce-nest-pas-demain-que$\underline{\text { les-homosexuels-etrangers-envahiront-le-canada }}$

LaViolette, N. (2004). Coming out in Canada: The immigration of same-sex couples under the Immigration and Refugee Protection Act. McGill Law Journal, 49, 969-1003.

LaViolette, N. (2007). Gender-related refugee claims: Expanding the scope of the Canadian guidelines. International Journal of Refugee Law, 19(2), 169-214. doi:10.1093/ijrl/eem008

LaViolette, N. (2009). Independent human rights documentation and sexual minorities: An ongoing challenge for the Canadian refugee determination process. International Journal of Human Rights, 13, 437-476. doi:10.1080/13642980902758234

Library and Archives Canada. (2014). The Canadian state. Retrieved from http://www.collectionscanada.gc.ca/canadian-state/023012-1616-e.html

Lee, E. O. J. (2018). Tracing the coloniality of queer and trans migrations: Resituating heterocisnormative violence in the Global South and encounters with migrant visa ineligibility to Canada. Refuge: Canada's Journal on Refugees, 34(1), 60-74.

Lee, E. O. J., \& Brotman, S. (2011). Identity, refugeeness, belonging: Experiences of sexual minority refugees in Canada. Canadian Review of Sociology, 48(3), 241-274. doi:10.1111/j.1755-618X.2011.01265.X 
International Journal of Child, Youth and Family Studies (2019) 10(1): 70-94

Lee, E. O. J., \& Brotman, S. (2015). Social work and sexual and gender diversity. In N. Ives, M. Denov, \& T. Sussman (Eds.), Social work histories, contexts and practices: A Canadian perspective (Ch. 10). Don Mills, ON: Oxford University Press.

Lee, E. O. J., Hafford-Letchfield, T., Pullen Sansfaçon, A., Kamgain, O., \& Gleeson, H. (2017). The state of knowledge about LGBTQI migrants living in Canada in relation to the global LGBTQI rights agenda. Montreal, QC: University of Montreal.

Lee, W. J. E. (2015). The social organization of queer/trans migrations: The everyday experiences of queer and trans migrants with precarious status [Doctoral dissertation]. McGill University, Montreal, QC.

Lowe, L. (2006). The intimacies of four continents. In L. A. Stoler (Ed.), Haunted by empire: Geographies of intimacy in North American history (pp. 191-212). Durham, NC: Duke University Press.

Luibhéid, E. (2005). Introduction: Queering migration and citizenship. In E. Luibhéid \& L. Cantu, Jr. (Eds.), Queer migrations: Sexuality, U.S. citizenship, and border crossings (pp. xi-xlvi). Minneapolis, MN: University of Minnesota Press.

Luibhéid, E. (2008a). Queer/Migration: An unruly body of scholarship. GLQ: A Journal of Lesbian and Gay Studies, 14(2-3), 169-190. doi:10.1215/10642684-2007-029

Luibhéid, E. (2008b). Sexuality, migration and the shifting line between legal and illegal status. GLQ: A Journal of Lesbian and Gay Studies, 14(2-3), 289-315. doi:10.1215/106426842007-034

Macklin, A. (2005). Disappearing refugee: Reflections on the Canada-US Safe Third Country Agreement. Columbia Human Rights Law Review, 36, 365-426.

Manalansan, M. F., IV. (1997). In the shadows of stonewall: Examining gay transnational politics and the diasporic dilemma. In L. Lowe \& D. Lloyd (Eds.), The politics of culture in the shadow of capital. Durham, NC: Duke University Press.

Manalansan, M. F., IV. (2003). Global divas: Filipino gay men in the diaspora. Durham, NC: Duke University Press.

Manalansan, M. F., IV. (2006). Queer intersections: Sexuality and gender in migration studies. International Migration Review, 40(1), 224-249. doi:10.1111/j.1747-7379.2006.00009.x

Manalansan, M. F., IV. (2014). The "stuff" of archives: Mess, migration and queer lives. Radical History Review, 120, 94-106. doi:10.1215/01636545-2703742

Massad, J. A. (2007). Desiring Arabs. Chicago, IL: University of Chicago Press. 
International Journal of Child, Youth and Family Studies (2019) 10(1): 70-94

Meyer-Cook, F., \& Labelle, D. (2004). Namaji: Two-Spirit organizing in Montreal, Canada. Journal of Gay and Lesbian Social Services, 16(1), 29-51. doi:10.1300/J041v16n01_02

Miluso, B. (2004). Family “de-unification in the United States: International law encourages immigration reform for same-gender binational partners. Washington International Law Review. 36, 915-923.

Morgensen, S. L. (2011). Spaces between us: Queer settler colonialism and Indigenous decolonization. Minneapolis, MN: University of Minnesota Press.

Mullaly, B. (2010). Challenging oppression and confronting privilege (2nd ed.). Don Mills, ON: Oxford University Press.

Murray, D. A. B. (2016). Real queer? Sexual orientation and gender identity refugees in the Canadian refugee apparatus. London, UK: Rowman \& Littlefield.

Nicol, N., Gates-Gasse, E., \& Mulé, N. J. (2014). Envisioning global LGBT human rights: Strategic alliances to advance knowledge and social change. Scholarly and Research Communication, 5(3), Article ID 0301165, 16 pp. Retrieved from http://srconline.ca/index.php/src/article/view/165/343

Naples, N. (1996). A feminist revisiting of the insider/outsider debate: The "outsider phenomenon" in rural Iowa. Qualitative Sociology, 19(1), 83-106.

doi:10.1007/BF02393249

$\mathrm{Ng}$, R. (2006). Exploring the globalized regime of ruling from the standpoint of immigrant workers. In C. Frampton, G. Kinsman, A. K. Thompson, \& K. Tilleczek (Eds.), Sociology for changing the world: Social movements/social research (pp.174-188). Fernwood publishing: Halifax.

Oba, Y., \& Pope, M. (2013). Counseling and advocacy with LGBT international students. Journal of LGBT Issues in Counselling, 7(2), 185-193. doi:10.1080/15538605.2013.785468

Perez, H. (2005).You can have my brown body and eat it too! Social Text, 23 (3-4 (84-85)), 171192. doi:10.1215/01642472-23-3-4_84-85-171

Puar, J. (1996). Transnational sexualities: South Asian (trans)nation(alism)s and queer disaporas. In R. Leong (Ed.), Asian American sexualities: Dimensions of the gay and lesbian experience (pp.405-422). New York, NY: Routledge.

Rehaag, S. (2008). Patrolling the borders of sexual orientation: Bisexual refugee claims in Canada. McGill Law Journal, 53, 59. Retrieved from http://ssrn.com/abstract=1468712 
International Journal of Child, Youth and Family Studies (2019) 10(1): 70-94

Rehaag, S. (2009). Bisexuals need not apply: A comparative appraisal of refugee law and policy in Canada, the United States, and Australia. International Journal of Human Rights, 415(13). doi:10.1080/13642980902758226

Ricard, N. (2011). Le prix à payer pour devenir sujet de droit: La selection des réfugiés allosexuels au Canada [The price of becoming a legal subject: The selection of queer refugees in Canada]. Alterstice, 1(2), 79-96. Retrieved November 1st 2014 from http://journal.psy.ulaval.ca/ojs/index.php/ARIRI/article/view/Ricard_Alterstice1\%282\%29.

Ricard, N. (2014). Testimonies of LGBTIQ refugees as cartographies of political, sexual and emotional borders. Journal of Language and Sexuality, 3(1), 28-59. doi:10.1075/jls.3.1.03ric

Rivera-Silber, N. (2013). "Coming out undocumented" in the age of Perry. New York University Review of Law \& Social Change, 37(1), 71.

Roy, O. (2012). The colour of gayness: Representations of queers of colour in Québec's gay media. Sexualities, 15(2), 175-190. doi:10.1177/1363460712436541

Sears, C. (2008). All that glitters: Trans-ing California's gold rush migrations. GLQ: A Journal of Lesbian and Gay Studies, 14(2-3), 383-402. doi:10.1215/10642684-2007-038

Serano, J. (2007). Whipping girl: A transsexual woman on sexism and the scapegoating of femininity. Emeryville, CA: Seal.

Simpson, A. (2014). Mohawk interruptus: Political life across the borders of settler states. Durham, NC: Duke University Press.

Smith, D. E. (1990). The conceptual practices of power: A feminist sociology of knowledge. Toronto, ON: University of Toronto Press.

Smith, D. E. (2005). Institutional ethnography: A sociology for people. Lanham, MD: AltaMira.

Smith, D. E. (2006). Institutional ethnography as practice. Lanham, MD: Rowman \& Littlefield.

Smith, G. W. (1990). Political activist as ethnographer. Social Problems, 37(4), 629-648. doi:10.1525/sp.1990.37.4.03a00140

Smith, G. W. (2006). Political activist as ethnographer. In C. Frampton, G. Kinsman, A. K. Thompson, \& K. Tilleczek (Eds.), Sociology for changing the world: Social movements/social research (pp. 44-70). Halifax, NS: Fernwood.

Solomon, A. (2005). Trans/Migrant: Christina Madrazo's all-American story. In E. Luibhed, L. Cantu, Jr. (Eds.), Queer migrations: Sexuality, US citizenship, and border crossings (pp. 329). Minneapolis, MN: University of Minnesota Press. 
International Journal of Child, Youth and Family Studies (2019) 10(1): 70-94

Spade, D. (2011). Normal life: Administrative violence, critical trans politics and the limits of law. Brooklyn, NY: South End.

Stryker, S. (2008). Transgender history. Berkeley, CA: Seal.

Terriquez, V. (2015). Intersectional mobilization, social movement spillover, and queer youth leadership in the immigrant rights movement. Social Problems, 62(3), 343-362. doi:10.1093/socpro/spv010

Todd, N., \& Wade, A. (1994). Domination, deficiency, and psychotherapy. The Calgary Participator, Fall, 37-46.

Wade, A. (1997). Small acts of living: Everyday resistance to violence and other forms of oppression. Journal of Contemporary Family Therapy, 19, 23-39.

Walcott, R. (2006). Black men in frocks: Sexing race in a gay ghetto (Toronto). In C. Teelucksingh (Ed.), Claiming space (pp. 121-133). Waterloo, ON: Wilfrid Laurier University Press.

White, M. A. (2013). Ambivalent homonationalisms: Transnational queer intimacies and territorialized belongings. Interventions, 15(1), 37-54. doi:10.1080/1369801X.2013.770999

Zaske, A. K. R. (2006). Love knows no borders - The same-sex marriage debate and immigration laws. William Mitchell Law Review, 32(2), Art. 9. 